Journal

of Geography

Politics and Society

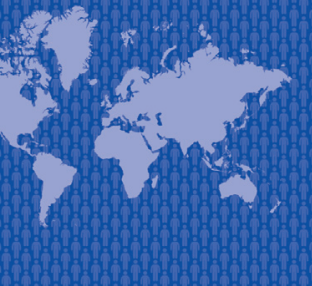

$7(2) / 2017$

\section{Journal of Geography, Politics and Society}

$2017,7(2), 24-31$

DOI 10.4467/24512249JG.17.012.6628

\title{
TOPICAL ISSUES OF SUSTAINABLE USE OF NATURAL RESOURCES OF THE WESTERN UKRAINIAN BORDERLAND
}

\author{
Valeriy Rudenko (1), Yaroslav Ivakh (2), Oleh Veklyn (3) \\ (1) Chair of Economic Geography and Ecological Management, Faculty of Geography, Yuriy Fedkovych National University of Chernivtsi, Kotsiubynsky 2, \\ 58012 Chernivtsi, Ukraine, \\ e-mail: rudenko_valery@ukr.net (corresponding author) \\ (2) Chair of Economic and Social Geography, Faculty of Geography, Ivan Franko National University of Lviv, Doroshenka 41, 79000 Lviv, Ukraine, \\ e-mail: ivakh.yaroslav@gmail.com \\ (3) Chair of Economic and Social Geography, Faculty of Geography, Ivan Franko National University of Lviv, Doroshenka 41, 79000 Lviv, Ukraine, \\ e-mail: oleg19v@gmail.com
}

\section{Citation}

Rudenko V., Ivakh Ya., Veklyn O., 2017, Topical issues of sustainable use of natural resources of the Western Ukrainian borderland, Journal of Geography, Politics and Society, 7(2), 24-31.

\begin{abstract}
The article analyzes the natural resource potential of the Western Ukrainian borderland: history, development, current state and conditions. Land resources and land fund of the Borderland as well as the main trends in its use as the basis of agriculture and the operational base of society have been characterized. The role of water, biological and recreational resources in the structure of the natural resources of the region has been described. Current trends in the use of Western Ukrainian borderland mineral resources have been analyzed.
\end{abstract}

\section{Key words}

Western Ukrainian borderland, natural resources, land resources, land fund, biological resources, forest resources, mineral resources, recreational resources, territorial combination of natural resources.

\section{Introduction}

Oblasts of Western Ukrainian borderland are characterized by a vast variety of natural resources, especially renewable ones. For centuries, land and biological resources have been the basis of economic development here. The maximum level of tillage was observed in the first half of the 20th century, which was associated with extreme agrarian overpopulation in the Borderland. In medieval times, the only mineral resources mined included salt, building materials and bog ore in limited quantities. In the second half of the 19th century, active development of oil, ozokerite, building materials began. One hundred years ago, Boryslav used to be one of the leading oil regions of the world. Construction of railways including narrow-gauge railroads enabled active exploitation of forest resources in the previously inaccessible areas.

After inclusion of Western Ukraine into the USSR (1939-1945), special attention was paid to the minerals needed for the region industrialization and electrification. In the 1950s, extensive works on the inventory of natural resources of the Western 
Ukrainian borderland were carried out. They resulted in a monograph published by the then head of the Chair of Economic Geography of Lviv State University O. Vashchenko "Natural Resources of the Western Regions of the USSR" (Ващенко, 1959).

Modern political, economic, technological and environmental challenges have a significant impact on natural resource potential of the Borderland:

- collapse of the Soviet Union, the fact that Ukraine became independent stopped the practice of large-scale pillage of natural resources at low prices in the interests of the empire. The fall of the "iron curtain" led to the slow, but steady, integration of the region into the European Area;

- new trends in mineral raw materials mining and processing result in another approach to the estimation of mineral resources. For example, "shale revolution" enables the search for oil and gas in the areas that used to be believed unpromising;

- since Ukraine became independent, the number of protected areas has significantly increased. Western Ukrainian borderland has the highest protection indicator in the country, which affects the total natural resource potential.

With a view to a comprehensive study of natural resources in modern conditions, O. Shabliy (Шаблій, 2001) proposed a combined classification of natural resources which combined geosphere and humangeographical approaches. Resources are estimated considering diverse material but also spiritual needs of the society. Since in the last few years, there were fundamental changes in the political and economic situation in Ukraine, this requires new approaches to the characterization of natural resources of Western Ukrainian borderland.

\section{Assessment of Natural Resources Potential Structure of Western Ukrainian Borderland}

V. Rudenko (Руденко, 2010) conducted an economic assessment of natural resource potential of Ukraine based on the use value of mineral, water, land, forest fauna and natural-recreational resources. Share of the Western Ukrainian borderland amounts to around $179.86 \%$ of the total potential of Ukraine (Tab. 1). Its structure in all the western oblasts of Ukraine, except Zakarpattia and Ivano-Frankivsk oblasts, is dominated by land resources. Water and recreational resources are the most important ones in these two oblasts also characterized by high proportion of forest resources. The most balanced natural resource potential is typical to Lviv oblast where the share of land resources accounts for about onethird of the potential, and the remaining share is evenly distributed among other types of resources.

\section{Land Resources}

Land resources of the Western Ukrainian borderland constitute $45 \%$ of the total cost. In the Volyn oblast, this share exceeds 50\%, and in Khmelnytskyi and Ternopil oblasts it exceeds $75 \%$. High assessment of the lands of Khmelnytskyi and Ternopil oblasts is explained not only by high natural fertility, but the largest share of arable land, which constitutes more than $60 \%$ of the area (Fig. 1). The area of agricultural land in mountainous Zakarpattia, Ivano-Frankivsk and Chernivtsi oblasts is limited, however some areas of the northeastern Prykarpattia and Bukovyna have a very high potential of land resources.

Tab. 1. Natural resources potential of Western Ukrainian borderland

\begin{tabular}{|c|c|c|c|c|c|c|c|}
\hline \multirow[b]{2}{*}{ Administrative units } & \multicolumn{7}{|c|}{ Resources potential, in \%o of the value } \\
\hline & 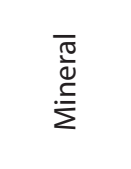 & $\frac{\overline{ \pm}}{\stackrel{ \pm}{\pi}}$ & 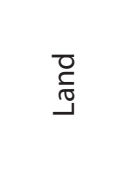 & 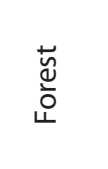 & 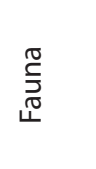 & 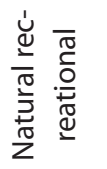 & $\begin{array}{l}\overline{0} \\
\stackrel{0}{ \pm} \\
\stackrel{ \pm}{=}\end{array}$ \\
\hline Lviv oblast & 8.491 & 8.539 & 11.011 & 4.169 & 0.066 & 5.377 & 37.653 \\
\hline Zakarpattia oblast & 0.753 & 7.751 & 4.767 & 4.294 & 0.020 & 7.036 & 24.621 \\
\hline Ivano-Frankivsk oblast & 1.676 & 7.529 & 5.453 & 3.983 & 0.030 & 3.929 & 22.600 \\
\hline Chernivtsi oblast & 0.658 & 2.324 & 6.354 & 1.596 & 0.027 & 1.744 & 12.703 \\
\hline Volyn oblast & 0.160 & 3.051 & 9.340 & 2.749 & 0.069 & 1.557 & 16.926 \\
\hline Rivne oblast & 0.088 & 2.895 & 9.685 & 2.842 & 0.132 & 1.171 & 17.605 \\
\hline Ternopil oblast & 0.261 & 2.862 & 15.792 & 0.982 & 0.032 & 1.136 & 21.085 \\
\hline Khmelnytskyi oblast & 0.929 & 3.675 & 19.385 & 1.014 & 0.096 & 1.600 & 26.699 \\
\hline Western Ukrainian borderland & 13.016 & 38.626 & 81.787 & 21.629 & 0.472 & 23.550 & 179.862 \\
\hline Ukraine & 282.558 & 130.759 & 443.839 & 41.699 & 4.739 & 96.406 & 1000.000 \\
\hline
\end{tabular}

Source: Руденко, 2010. 
In recent decades, the share of arable land, especially in Polissia and Prykarpattia is gradually decreasing, some of the land plots turned into abandoned fields. This is due to several reasons. First of all, land with low natural fertility is not tilled. In addition, there are significant socio-economic factors. In early 1990s, most rural residents were trying to get maximum plots for farming (sometimes more than 1 ha). Subsequently, many farmers became migrant workers and abandoned farming. Therefore, there is a correlation between the percentage of migrant workers and abandoned land plots.

In general, soil and agro-climatic resources of Western Ukrainian borderland, though inferior to other regions of Ukraine, have great potential due to better moisture conditions. In Europe, better natural properties are typical to Hungarian land resources and those of some regions of France only.

In the Western Ukrainian borderland, a trend of decrease in the arable land is observed (Fig. 2). In 1990-2015, area of arable lands possessed and used by all enterprises decreased by 459500 ha and in 2015 amounted to 4882000 ha. In Zakarpattia oblast only, during this period, arable land area increased by 4200 ha. Instead, the most significant decrease in the arable land area was observed in Lviv (145 600 ha), Khmelnytskyi (95 000 ha) and Volyn (75 400 ha) oblasts.

There are many issues with the real valuation of agricultural land due to a lack of land market. The average normative monetary evaluation of 1 ha of arable land as of January 1, 2017 is 30 927.8 UAH (1 137 USD) (Державна служба геодезії..., 2017). However, in some remote areas of Polissia, Little Polissia, Prykarpattia, it will amount to less than $10000 \mathrm{UAH}$. However, the land plots in suburban areas with good natural fertility and high differential rent might cost hundreds of thousands UAH per hectare. Price of arable land in Khmelnytskyi, Ternopil oblasts, in southern Rivne and Volyn oblasts, where the chernozem and dark gray forest soils predominate, is higher than average. In case of lifting the moratorium on the sale of agricultural land, experts predict a threefold rise in the cost of 1 ha - up to 2990 USD. This price range will vary from 1480 to 6030 USD per 1 hectare (Нізалов et al., 2016).

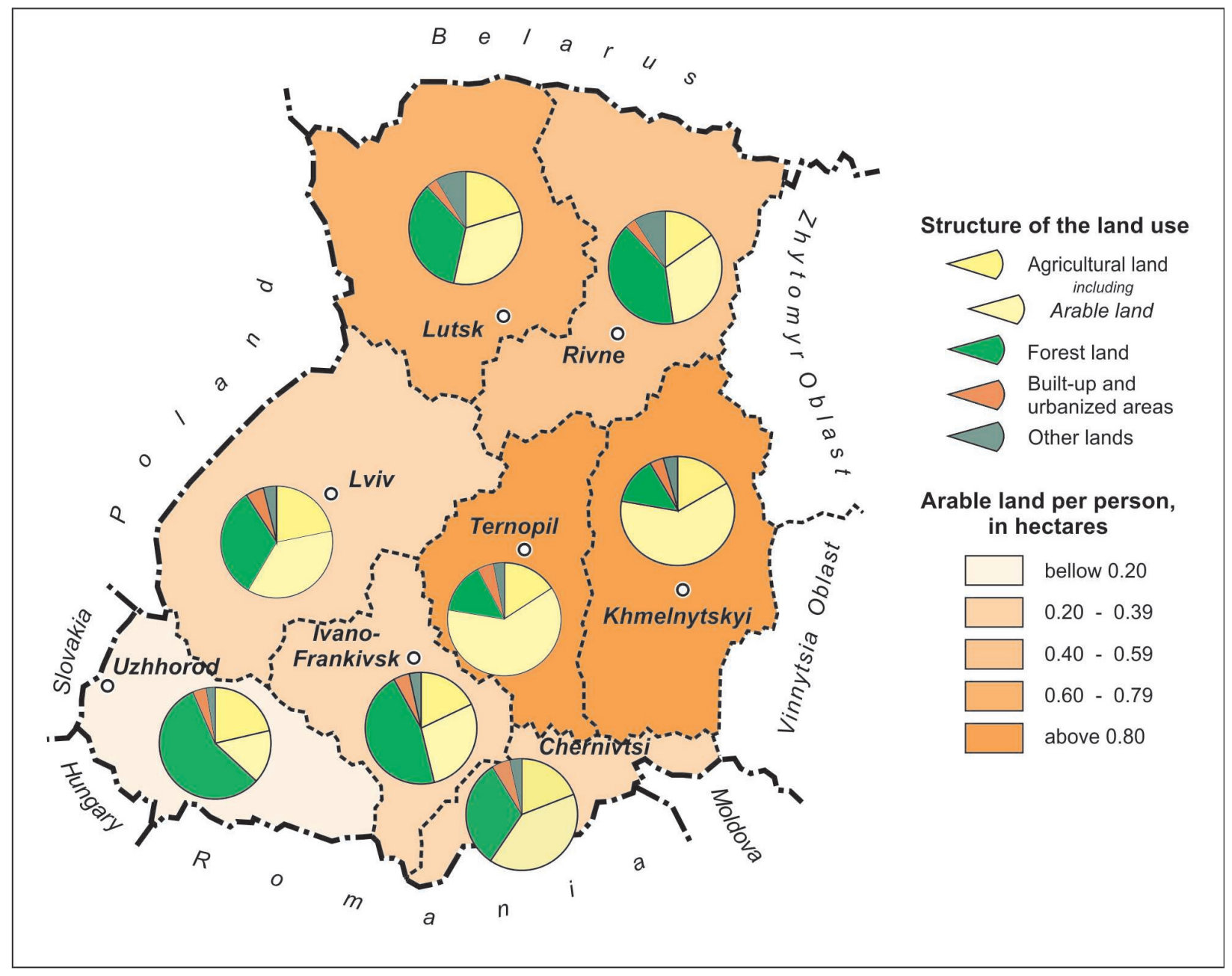

Fig. 1. Land use of Western Ukrainian borderland, 2015

Source: Own calculation and mapping based on Довкілля України..., 2016. 


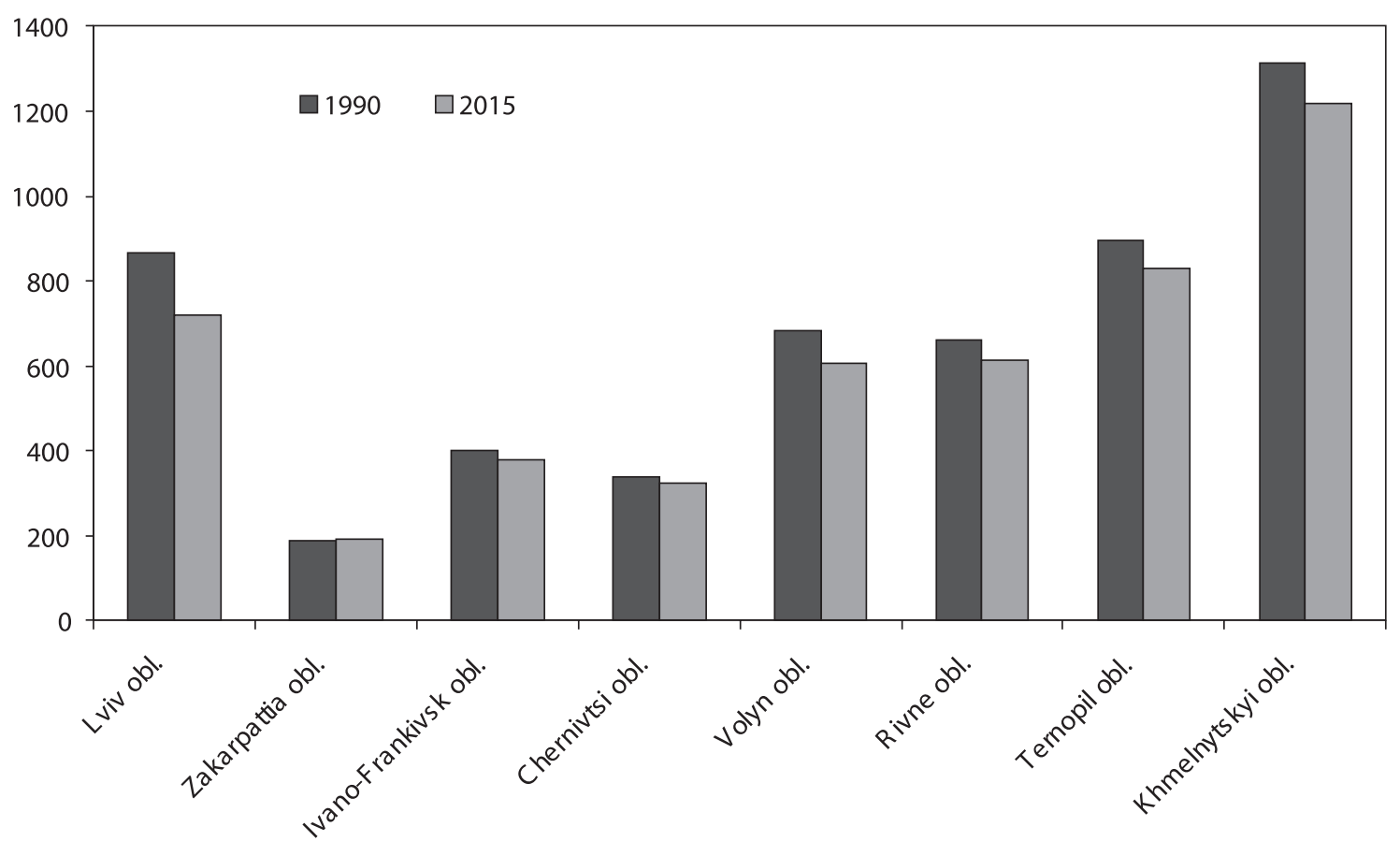

Fig. 2. Area of arable lands possessed and used by all enterprises of Western Ukrainian borderland, 1990-2015 Source: made by authors, based on Регіони України..., 2016; Регіони України..., 2004.

Ukraine has already formed a market for nonagricultural land, especially for the land for residential development. Due to higher population density, lower urbanization level, presence of hundreds of thousands of migrant workers in each area, land for development in the Western Ukrainian borderland is in high demand. The highest price is observed in cities and suburban areas. In Ukraine, it ranges from 1000 to 4000 USD per are. A similar price of land was formed in the resort towns and villages of Truskavets, Morshyn, Yaremche, Vorokhta, Slavske, Skhidnytsia, Yasynia, Mizhhiria, Shatsk, etc.

\section{Water Resources}

The role of water resources of Western Ukrainian borderland of national and international significance is increasing. The region accounts for over 40 percent of local runoff of Ukraine ( $50 \%$ of the surface and almost $60 \%$ of the groundwater runoff) (Tab. 2.). More than $90 \%$ of the total runoff of the Dnister, $50 \%$ of the Prut, $25 \%$ of the Tysa, more than $10 \%$ of the Dnipro, the Southern Bug, and the Vistula are formed here. Unfortunately, more than half of local runoff gets outside of the borders of Ukraine through the basins of different rivers: the Tysa which irrigates the entire eastern part of Hungary, the Dnister and the Prut which limit the territory of Moldova and are critical for the water supply in the country; the Western Bug and the San which ensure, though to a lesser extent, water balance of Poland; the Siret River and smaller rivers of Bukovyna flowing through Romania. The Dnister and the Southern Bug largely supply water to the south-western part of Ukraine.

Tab. 2. Average long-term value of the water balance components of the Western Ukrainian borderland oblasts

\begin{tabular}{|l|c|c|}
\hline \multirow{2}{*}{ Administrative units } & \multicolumn{2}{|c|}{ Runoff, $\mathrm{km}^{3}$} \\
\cline { 2 - 3 } & Surface & Groundwater \\
\hline Lviv oblast & 3.27 & 1.65 \\
\hline Zakarpattia oblast & 6.39 & 1.53 \\
\hline Ivano-Frankivsk oblast & 3.33 & 1.26 \\
\hline Chernivtsi oblast & 0.93 & 0.30 \\
\hline Volyn oblast & 1.58 & 0.60 \\
\hline Rivne oblast & 1.56 & 0.77 \\
\hline Ternopil oblast & 1.01 & 0.80 \\
\hline Khmelnytskyi oblast & 1.58 & 0.56 \\
\hline $\begin{array}{l}\text { Western Ukrainian } \\
\text { borderland }\end{array}$ & $19.65(49.9 \%)$ & $7.47(57.5 \%)$ \\
\hline Ukraine & $39.4(100.0 \%)$ & $13.0(100.0 \%)$ \\
\hline
\end{tabular}

Source: Щербак, 1989.

For most Western Ukrainian borderland, water resources are redundant and can be used for the development of aqueous production. In Polissia and Little Polissia, there are small tracts of protected wetlands regulating surface runoff of the rivers and being biodiversity hotspots. In the region, there are no large lakes and reservoirs (except a group of Shatsky lakes 
and Dnister reservoir). All this poses certain threats to borderland water balance in dry years as was the case in the summer and autumn 2015 (July-November) and summer 2016 (June-September).

Since most of the settlements of the Borderland take water from the underground sources, recent years have seen a dramatic groundwater lowering. The reasons for this are not only shortage of water in the recent years, but first of all significant increase in the individual water supply in the rural areas. With the current trends of global climate change, Western Ukrainian borderland may be the key to water security of Ukraine and neighboring Moldova.

\section{Biological Resources}

Biological resources of the region are primarily represented by forests. Western Ukrainian borderland has the highest forest coverage in Ukraine while Carpathian forests have the highest stand of timber per unit area (Fig. 3). Official statistics shows an increase in forest area, but there is no reliable data on forested areas. The real situation is much worse as illegal logging is performed in large areas. In most cases, public attention and that of the academia is focused on the destruction of the Carpathian forests. The problem is really crucial there because of a number of related adverse natural processes. Barbaric deforestation without saving young growth and undergrowth causes almost complete washout of soil, increase in erosion, landslides, and catastrophic floods. Forest self-restoration without anti-erosion and forestry measures is virtually impossible.

However, a much larger area of deforestation is typical to Polissia. This is explained by easy forest exploitation on the plains and species composition of the forest. It is dominated by pines and oaks which are highly liquid commodity in the European and Ukrainian markets. Loggings are mainly conducted in the middle of vast forests massifs, which given the flat terrain allows visually hiding the real area of

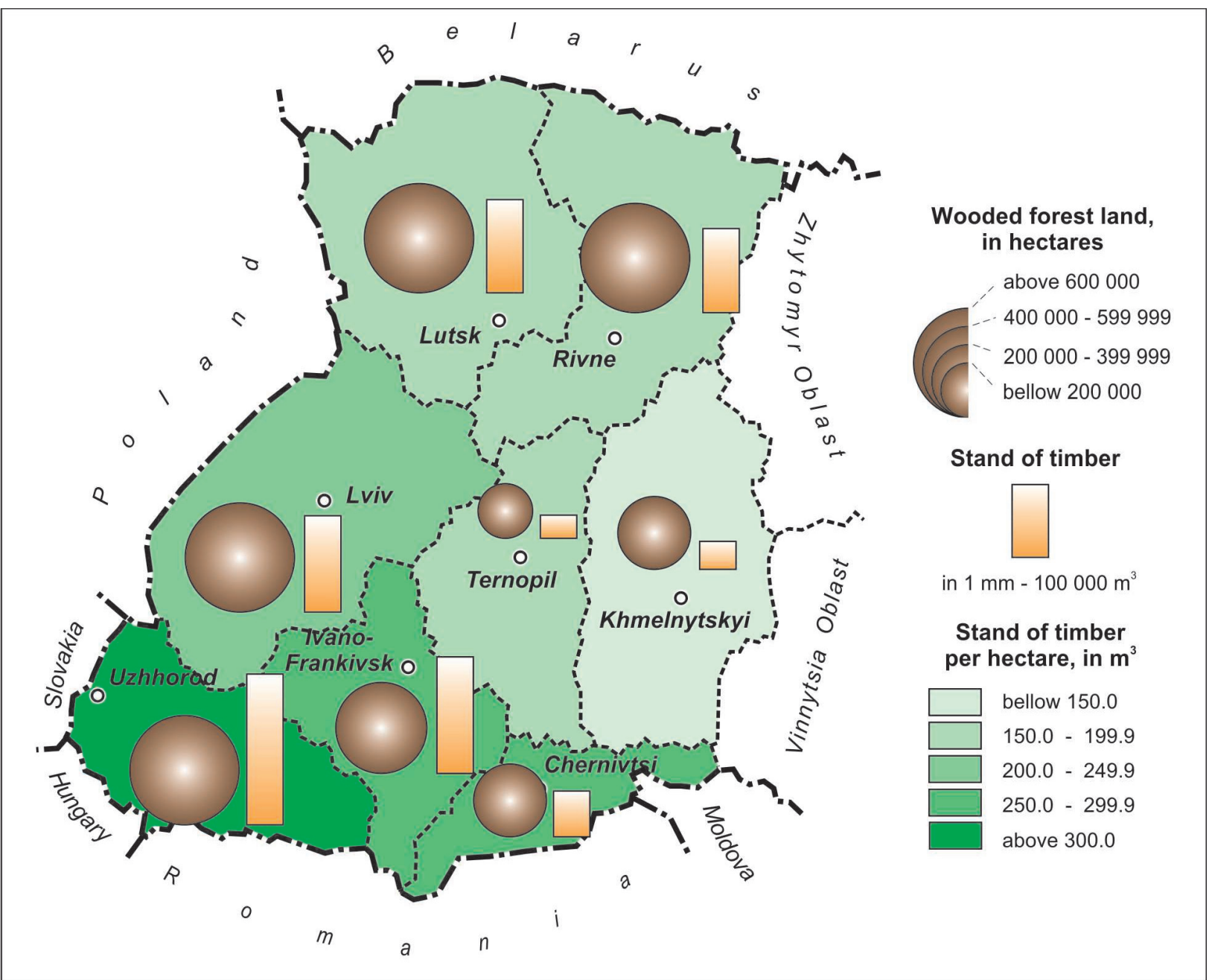

Fig. 3. Wooded forest land and stand of timber of the Western Ukrainian borderland, 2015

Source: Own calculation and mapping based on Довкілля України..., 2016; Лісовий ресурс...; Загальна характеристика лісів...; Лісівництво...; Паспорт області...; Ліси Івано-Франківщини...; Лісове господарство...; Загальна характеристика області...; Лісове господарство Львівської області... . 
forest destruction. It can be seen on a satellite image only. Lack of erosion, rapid decomposition of logging residues promotes the process of forests selfrestoration, which in several years are presented as the areas where afforestation was conducted.

Roztochia and Podilia forests are much better preserved because of the high share of protected areas and the predominance of hornbeam and beech stands which are of limited use in woodworking and pulp and paper industries. However, gradual transition of the woodwork industry to the production of pressed beam and a sharp rise in gas prices, which leads to decrease in firewood production, may threaten these forests.

Climate change has a significant impact on the biological productivity of forest resources. Warmer and wetter years promote maximum timber growth. However, prolonged drought of the last two years threatens conifers plantations in the Carpathians mountains (Picea Abies) and in Podilia where the mixed pine stands are gradually shrinking. In general, the potential of biological resources of the Western Ukrainian borderland in the last decades has significantly increased due to increase in the area of land covered with natural vegetation and protected areas, decrease in the use of pesticides in agriculture. Therefore, the herbs, berries, mushrooms biomass growth increased in spite of the fact that the actual reserves of these types of resources require detailed study.

\section{Recreational Resources}

Recreational resources that range from $5-7 \%$ in Ternopil, Khmelnytskyi, Rivne oblasts, to $17-28 \%$ in Ivano-Frankivsk and Zakarpattia oblasts are of increasing importance for the socio-economic complex of the Western Ukrainian borderland. In terms of the structure, they are very close to those of the neighboring states - Poland, Slovakia, Hungary and other Middle European countries. Truskavets and Skhidnytsia are characterized by unique hydrogen sulfide springs. Resources of the Western Ukrainian borderland are especially important for the Ukrainian recreational services market (skiing, hiking, educational tourism). In dry and hot summer weather it is only in the Carpathians and Polissia that pleasant coolness for a rest can be found by the residents of industrial regions of Ukraine.

Combination of historical and cultural resources gives a dramatic increase in the potential of natural recreational resources. The presence of many architectural monuments, operating sacred sites, preserved traditions and scenic landscapes create synergistic effect that promotes the efficient use of natural resources. Western Ukrainian borderland is a combination of the Middle European-type resources with lower infrastructure development level and a wide range of prices. The cheapest is independent tourism and recreation which cost is actually the cost of transfer and food. Access to most protected areas and museum is significantly lower than the prices of the services in neighboring countries. Therefore, these trips through Western Ukraine, which unlike in the neighboring regions of unorganized tourism, attract residents of the European countries. In future, the opportunity to see "Europe at reduced prices" will be used by the tourists from Asia, particularly China.

\section{Mineral Resources}

Mineral resources of the Borderland are in need of substantial revaluation. The fuel-energy and chemical raw materials deposits, which used to be of national and international importance, are still heavily depleted and cannot so much as meet regional needs.

However, building materials resources are extremely diverse. Rivne granite, sandstone of Prydnisteria and the Carpathians, limestone of Podilia are the best known resources. There are huge deposits of cement and brick raw material, gypsum, construction and glass sand, gravel and gravel-pebble mixtures. The cost of one ton of materials is low, but their recoverable reserves alone are estimated at billions of tons making their deposits the most valuable ones among the mineral resources. Materials are ubiquitous which makes them an important economic basis for local communities. Unfortunately, a large amount of building materials is mined illegally or semi-legally, which causes a lot of environmental problems. A similar situation is observed with the production of unique amber deposits in Polissia, especially in the Rivne oblast.

Salt mining, mostly from brines, has been an important mainstay of the Peredkarpattia economy for centuries. Because of high energy consumption in salt evaporation and complex hydrogeological conditions in Solotvyn field (Zakarpattia), salt mining in the Western Ukrainian borderland was almost terminated (except Drohobych), though the deposits are quite large. Potassium salts in Kalush are being developed now and production in Stebnyk has been suspended. These deposits could meet the needs of Ukraine, but mining requires modern technology and investment to solve numerous environmental problems. Instead, still quite large deposits of sulfur 
in the districts of Yavoriv and Novyi Rozdil should be suspended for the coming decades as overproduction is observed in the world.

Considerable oil deposits in Peredkarpattia were exhausted back in the first half of the 20th century, and those of gas - in the second half. Now, significant oil and gas deposits have been developed in Zakarpattia and Volyn, and those of the shale gas in Podilia (Olesko deposit). However, low prices for hydrocarbons in recent years, the lack of investors and technology move real estimation of the oil and gas deposits and their development to longer term.

The small Lviv-Volyn coal basin is just southeastern outskirts of much larger Lublin basin, which is almost not developed in Poland. Most mines of Chervonohrad and Novovolynsk have already depleted productive strata and are in need of closure. Promising areas (Tiahliv and Lubela areas) have difficult conditions of production and too small deposits for profitable production under modern conditions. The peat deposits in Polissia and locally in Peredkarpattia should be used as valuable organic fertilizer.

\section{Territorial Combination of Natural Resources}

Natural resources are often located geographically close which is positive for their use. These territorial combinations of resources can be formed of resources of various earth sectors. For example, let us consider the unique mineral water of Truskavets, resources of chemical industry (potassium salt) of Stebnyk and oil and gas deposits of Drohobych region. We get a kind of local combination of natural resources - Boryslav-Truskavets region.

In the mountainous part of Western Ukrainian borderland, mineral water resources of different material and gas composition are distinctly combined. Ten local combinations are identified: Svaliava, Mizhhiria, Tiachiv, Yasinia-Rakhiv, Novoselytsia, Putyla, Kosiv, Morshyn-Bolekhiv, Truskavets-Skhidnytsia, Kalush-Solotvyn.

Almost all of them contain fuel and energy and chemical resources:

1. Boryslav-Truskavets (mineral water, potassium salt, oil, gas).

2. Dolyna-Morshyn (oil, gas, potassium salt, mineral ozokerite).

3. Rakhiv-Solotvyn (rock salt, natural gas).

4. Kalush-Solotvyn (potassium salt, mud, fuel gas, etc.).

5. Putyla (oil, natural gas, ozokerite, etc.).

In these territorial combinations, problem of priority use of a natural resource arises, i.e. the problem of determining the region specialization as the use of a resource creates problems for the use of the other one. For example, mining creates significant problems for the use of recreational resources and development of recreational infrastructure.

Environmental component should be the main criterion in determining the priority of the development and use of natural resource combination. The next criteria should include social and economic benefits from natural resources.

\section{Conclusions}

Thus, the raw material focus of the economy of the Western Ukrainian borderland is in the past. A sharp increase in the price of fossil fuels (especially after the implementation of the Paris Agreement), which would let us consider the proven deposits of the tens of millions of tons of oil and hundreds of millions of tons of coal as an important resource for development, is unlikely. However, almost half of not yet used hydropower resources of Ukraine and good conditions for the development of wind, solar, geothermal energy are concentrated here.

It is the alternative energy sources that could become a new economic growth point of the Western Ukrainian borderland. In addition to solar and wind energy, there are great prospects for biogas production, tens of millions of tons of organic waste and the development of geothermal energy in Zakarpattia oblast can become raw materials base. The share of recreational resources of the Borderland, which have already become a strong basis for the development of tourism and health-resort complex, will increase. However, the recreational resources potential of the region is not used enough, especially in Podilia, Oppilia and in many regions of Polissia.

Land resources will not lose their importance. The introduction of modern technologies has already made medium and low fertile land that hasn't been in use in the early 2000s attractive for agribusiness. In addition, convenient economic and geographical location, dense transportation network result in a constant growth in prices of land as a territorial resource. The role of water resources in the region on the national and international level will be undoubtedly growing.

Generally in the region, there is a pan-European trend to mining shutdown, more efficient use of renewable resources and successful launch of alternative energy. 


\section{References}

Ващенко П., 1959, Природні ресурси західних районів УРСР, Книжково-журнальне видавництво, Львів.

Державна служба геодезії, картографії та кадастру. Огляд стану земельних відносин в Україні, 1 березня 2017 р., http://land.gov.ua/opublikovano-cherhovyi-vypuskshchomisiachnoho-land-review/ [07.03.2017]

Довкілля України, Статистичний збірник за 2015 рік, 2016, Державна служба статистики України, Київ.

Загальна характеристика лісів Рівненщини, Рівненське обласне управління лісового та мисливського господарства, http://rivnelis.gov.ua/material/119 [12.03.2010].

Загальна характеристика області, Чернівецьке обласне управління лісового та мисливського господарства, http://www.cvoulg.cv.ukrtel.net/harakter.html [12.03.2010].

Ліси Івано-Франківщини, Івано-Франківське обласне управління лісового та мисливського господарства, http://www.ifforestry.gov.ua/lisi-ivano-frankivshchini [12.03.2010].

Лісівництво, Тернопільське обласне управління лісового та мисливського господарства, http://ternopillis.gov. ua/work/lisivnytstvo [12.03.2010].

Лісове господарство Львівської області: сучасний стан, динаміка, проблеми та перспективи розвитку у 2016 році, Львівське обласне управління лісового та мисливського господарства, http://www.lvivlis.com.ua/ file/LG\%20suchasnyy\%20stan\%20i\%20perspektyvy\%20 2016.PDF [12.03.2010].

Лісове господарство, Закарпатське обласне управління лісового та мисливського господарства, https:// zakarpatlis.gov.ua/napryamky-diyalnosti/lisovehospodarstvo/ [12.03.2010].

Лісовий ресурс служить державі, Волинське обласне управління лісового та мисливського господарства, 24 вересня 2015 р., http://lis.volyn.ua/?p=10892 [12.03.2010].

Нізалов Д., Нів'євський О., Прокопенко О., 2016, Ціни на землю та обсяг ринку: на що очікувати в Україні, https://voxukraine.org/2016/01/18/land-prices-andsize-of-the-market-what-to-expect-for-ukraine-ua/ [07.03.2017].

Паспорт області, Хмельницька обласна рада, http://kmoblrada.gov.ua/khmelnytsky-region/ [12.03.2010].

Регіони України, Статистичний збірник за 2004 рік. Частина 2, 2004, Державний комітет статистики України, Київ.

Регіони України, Статистичний збірник за 2016 рік. Частина 2, 2016, Державна служба статистики України, Київ.

Руденко В., 2010, Географія природно-ресурсного потенціалу України, Чернівецький національний університет, Чернівці.

Шаблій О., 2001, Суспільна географія: теорія, історія, українознавчі студії, Видавничий центр Львівського національного університету імені Івана Франка, Львів.
Щербак А., 1989, Водний кадастр, [in:] Географічна енциклопедія України (Том 1: А-Ж.), Видавництво Українська Радянська Енциклопедія, Київ, 201. 